\title{
The Information-Seeking Habits of In-Service Educators
}

\section{Todd Shipman, Susan H. Bannon, and Kimberly Nunes-Bufford}

\begin{abstract}
Research on information literacy and educators has focused on preservice educators and learning information literacy skills. Little research exists on in-service educators and their information literacy skills. Purposes of this study were to identify information sources that in-service educators used; to determine relationships between information sources used and in-service educators' professional position, age groups, experience, and information format preference; and to determine relationships between in-service educators' information-seeking habits and prior library instruction. Results of this study indicated statistically significant relationships between information-seeking habits and prior library instruction. Other statistically significant in relationships were indicated between information-seeking habits and the age groups and current professional positions of sample population.
\end{abstract}

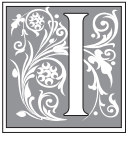

n 2000, the Association of College and Research Libraries (ACRL) approved and published the Information Literacy Competency Standards for Higher Education demonstrating the association's commitment to promoting the development of information literacy skills at colleges and universities and articulating the value of the instructional support provided by academic librarians in the changing environment of technological development and the rapid expansion of access to information resources. ${ }^{1}$ In 2011, ACRL approved and published standards developed by the Instruction for Educators Committee of the Educational and Behavioral Sciences Section (EBSS) of ACRL. The stated purpose for Information Literacy Standards for Teacher Education is to guide the development of information literacy instruction for teacher education students and to facilitate the evaluation of that instruction. A primary goal for using the standards, as stated by the committee, is to enable teacher education students "to develop a robust understanding of the role of information in their lives." 2 Consequently, research related to the information-seeking habits of in-service educators and their experiences with information literacy training via library instruction may benefit academic librarians who provide instruction to students in professional education programs. Additional data concerning the information-seeking habits of in-service

Todd Shipman is Education Librarian in Auburn University Libraries; e-mail: tas0011@auburn.edu; Susan H. Bannon is Associate Professor and Director in the Learning Resources Center at Auburn University; e-mail: bannosh@auburn.edu; Kimberly Nunes-Bufford is a Library Media Specialist at West Forest Intermediate School in the Opelika City Schools; e-mail: kimberly.nunes-bufford@opelikaschools.org. (C) 2015 Todd Shipman, Susan H. Bannon, and Kimberly Nunes-Bufford, Attribution-NonCommercial (http:// creativecommons.org/licenses/by-nc/3.0/) CC BY-NC. 
educators may also facilitate the assessment of information literacy programs and the effort for improvement in the instruction programs at academic libraries.

Educators in today's classrooms work in a digital world, and they have access to various information formats. At the same time, educators are implementing resource-based learning and evidence-based teaching practices, and they need information literacy skills to effectively locate and use information in their professional practice. Given the abundance of information sources currently available and the various means for searching and accessing information, this study provides data about the informationseeking habits of in-service educators and identifies factors that show a relationship to their information-seeking habits.

Research on information literacy as it relates to educators has focused primarily on preservice educators and their need to learn information literacy skills to teach those skills to their future students. Little published research exists on information literacy and the information seeking habits of in-service educators, especially when it concerns finding information for professional use.

\section{Literature Review}

After several in-depth literature searches, the authors are confident that most of the published literature related to information literacy and educators occurred during the past three decades and related to preservice educators and teacher education. Not much published literature about information literacy and in-service educators was available, and literature review was broadened to include information-seeking habits of preservice educators and teacher education faculty.

O'Hanlon focused on the role of library research and teacher education, and she recommended that teacher education programs require preservice teachers learn and practice research and information-seeking skills so they could be competent problemsolvers and able to evaluate the relevance of research studies for classroom practice. ${ }^{3}$ Franklin and Toifel found that bibliographic instruction delivered by qualified professional librarians was the most appropriate and effective method for providing preservice teacher education students with knowledge of library and research methods. ${ }^{4}$ Toifel and Franklin studied preservice educators and their technology skills used for locating electronic information resources in an academic library. They reported that preservice educators could more effectively locate information in electronic formats such as databases if they had attended library instruction provided by a professional librarian. ${ }^{5}$

Branch explored how preservice educators understood information literacy and resource-based learning and recommended that teacher educators redesign methods courses to help preservice educators learn the importance of teaching information literacy to their students. ${ }^{6}$ In a study to evaluate elementary education student teachers' perceived information literacy skills, Demiralay and Karadeniz found that student teachers' perceived information literacy self-efficacy skills were related to their computer experience, skills and frequency with using a computer and the Internet, and access opportunities to computer and Internet use. ${ }^{7}$

Several models or programs for how information literacy should be included in the curriculum for preservice educators were reviewed. Successful collaborative projects between academic librarians and teacher education faculty noted the importance of supporting preservice educators with their understanding of the importance of information literacy. ${ }^{8}$

A few publications focused on specific information literacy standards for teacher education. Beile conducted a validation study with preservice educators to develop an information literacy instrument for teacher education. ${ }^{9}$ Libutti and Gratch edited a 
casebook of teaching information retrieval skills for preservice education students and practitioners, and they included a revision of the 1981 bibliographic competencies for preservice educators. ${ }^{10}$ Templeton and Warner and Birch et al. reported on the importance of information literacy standards for teacher candidates to meet the National Council for Accreditation of Teacher Education standards. ${ }^{11}$ A revision of information literacy standards for preservice educators was recently published. ${ }^{12}$

LeBaron et al. examined Internet research by experienced in-service educators and found their participants used a broad range of resources when finding information. ${ }^{13}$ Landrum et al. noted the paucity of research related to in-service educators and how and from where they obtain information to guide their educational practices. They investigated educators' perceptions of the usability of information presented in two formats: data-based and personal such as information from a veteran teacher. Educators rated the personal format of information as more usable than data-based information. ${ }^{14}$ When studying in-service educators in the United Kingdom, Williams and Coles found that information literacy may be a factor in limiting the use of research information. From an information perspective, they noted that an educator's use of research information is likely to be enhanced by greater development of information literacy, more attention to strategies used to disseminate local information to educators, and development of an information culture in schools. Educators in their studies were motivated toward the use of research information, but their actual use of research information was limited..$^{15}$ In another study, which explored the online information-seeking habits of biology teachers, Perrault found that study participants significantly underused educational online resources designed to support teaching and learning activities. ${ }^{16}$

\section{Purpose for the Study}

While most research on information literacy and educators has focused on preservice educators, little research has focused on information-seeking habits of or information sources used by in-service educators. Purposes of this study were to identify information sources that in-service educators used; to determine relationships between information sources used and in-service educators' professional position, age groups, experience, and information format preference; and to determine relationships between in-service educators' information-seeking habits and prior library instruction.

\section{Methodology}

\section{Survey Design}

A survey was developed using information from research on preservice teacher educators and information literacy as well as Information Literacy Standards for Teacher Education. ${ }^{17}$ The survey included categorical and quantitative questions. Categorical questions included demographic information, such as position (in other words, teacher, principal, school librarian, and the like), areas of teacher certification, teaching experience, current grade level of teaching responsibility, highest level of degree completed, and age based on a range of years. Quantitative questions focused on experience with technology, types of information sources used, frequency of use of information sources, purposes for using information sources, and experiences with professional development and information-seeking strategies.

After the survey instrument was developed, it was reviewed by a panel of university and school librarians, and changes were made to the survey before dissemination. Pilot testing results indicated that the survey would take fifteen minutes to complete. Subsequently, the survey protocol was reviewed by the university's Institutional Review Board and approved for dissemination. A copy of the survey is in the Appendix. 


\section{Survey Content}

The survey added to and expanded upon the constructs previously explored by Neely. ${ }^{18}$ Some items were developed to collect data related to specific performance indicators in the ACRL Information Literacy Standards for Teacher Education. ${ }^{19}$ Survey questions were designed to collect data on demographic characteristics as well as on the respondents' information-seeking habits.

\section{Demographic Information}

Position. Respondents were asked to select the best description of their positions. Choices included only positions that require state certification: administrators, teachers, and instructional support personnel.

Years of Experience. Respondents were asked to indicate years of professional experience. They selected from three grouped categories: $0-5$ years, 6-10 years, and 11 or more years.

Levels of Education. Choices included the four college and/or university degree levels: bachelor's, master's, education specialist, and doctorate. Respondents were asked to indicate each level completed; multiple responses were allowed.

Age. Respondents identified the range of years during which they were born. Choices were: before 1946, 1946-1964, 1965-1980, and 1981 and after.

Library Instruction. Respondents were asked to indicate whether they had ever attended an instructional session in which a librarian presented information on how to search for articles using an online database. They were also asked to indicate in a multiple-response question the location where the library instruction had taken place. Choices included: college or university library during undergraduate program, college or university library during graduate program, a school library, a public library, or in a continuing education (professional in-service) workshop.

Preference of Information Format. Respondents indicated whether they preferred information in print format or online electronic format.

\section{Information-Seeking Habits}

Information Sources. Respondents indicated the frequency of their use of sixteen information sources using a seven-point Likert scale. The response options included the following frequencies: daily, 2-3 times a week, once a week, 2-3 times a month, once a month, less than once a month, and never.

Purposes. In a multiple-response question, respondents indicated the purposes for which they seek information for professional use. Respondents chose from a list of seven purposes for seeking information: action research on classroom practices, class exercises or projects, classroom management, lesson planning, a research paper, assessment tools or tests, and news affecting the education profession.

\section{Survey Dissemination}

Current teachers or administrators were the target audience for the survey. The survey was disseminated via e-mail to the professional development coordinators in a regional in-service center serving 15 school systems in a southern state. They were requested to disseminate the informed-consent notice and the survey hyperlink to all certified personnel. Eight school systems confirmed that the surveys were disseminated, and the survey was active from November 2011 through March 2012.

\section{Limitations}

Typical survey sampling techniques were not used because the survey was distributed to school systems served by a common regional in-service center in one state. 
Dependence on the professional development coordinators to distribute the surveys and remind educators to complete the survey could have limited responses. The online survey tool could also have limited responses if an educator started the survey but did not finish it, if the educator did not respond to the e-mail request from his or her system's professional development coordinator, or if the educator was not comfortable with responding to an online survey.

\section{Results}

\section{Respondents}

A total of 382 surveys were completed, and 34 surveys were not valid. The remaining 348 surveys were analyzed. The largest group of educators who responded to the survey identified themselves as classroom teachers $(64 \%, n=222)$. Of the remaining respondents, 8.6 percent $(n=30)$ were administrators, 4 percent $(n=14)$ were counselors, 3.7 percent $(n=13)$ were school librarians, 2.3 percent $(n=8)$ were reading coaches, 8.9 percent $(n=31)$ were special area teachers, and 8.4 percent $(n=29)$ identified themselves as "other." The reading coach position is a type of instructional support personnel who assists students who are struggling readers, provides professional development programs on literacy education to in-service educators, and promotes a school climate that supports achievement in literacy education.

Each school system in this study has at least one full-time certified school librarian in each school. Only one school system has a library services coordinator who is a certified school librarian and provides school library program leadership at the system level. The regional in-service center staff includes one full-time person who is a certified school librarian and who provides professional development on information literacy and instructional technology skills to in-service educators who participated in this study.

Survey results also indicated that 63.5 percent $(n=220)$ of respondents have more than 11 years of experience as educators. Those with 6 to 10 years of experience comprised 22 percent $(\mathrm{n}=76)$, and those with 0 to 5 years of experience comprised 14.5 percent $(n=50)$ of survey respondents.

In a multiple-response question, respondents were asked to indicate the college or university degrees they had completed. All of the participants reported that they had earned bachelor's degrees. In addition, a majority of respondents also indicated that they had at least one graduate degree. Results showed 70.4 percent $(n=245)$ had master's degrees, and 14.1 percent $(n=49)$ reported having specialist degrees. Finally, 3.2 percent $(n=11)$ indicated that they had doctorate degrees.

Survey respondents were also asked to identify the range of years in which they were born. The largest group of educators $(46 \%, n=162)$ indicated that they were born between 1965 and 1980 (Generation X). Baby Boomers, or those born between 1946 and 1964, represented 33 percent $(n=113)$ of respondents. The Millennials, those born 1981 and after, comprised 20 percent $(n=69)$ of respondents. One percent $(n=3)$ of respondents were considered the Silent Generation, those born before 1946.

When asked to indicate their preference for information in either print or online information, 65 percent $(n=209)$ of 321 respondents reported that they preferred information delivered online and 35 percent $(n=112)$ preferred information in print. Respondents were also asked to indicate whether or not they had previously participated in a library instruction session in which a librarian presented information on how to search for information using library databases. Of the 315 educators who responded to the question, 58 percent $(n=184)$ indicated they had participated in information literacy instruction led by a librarian and 42 percent $(n=131)$ indicated that they had not. Answering a multiple-response question, respondents identified the location where they had library information literacy instruction. 
Almost one third ( $n=114)$ of the 348 respondents indicated having received instruction at a school library and 15.8 percent $(n=55)$ had participated in instruction in a continuing education workshop. Only 4 percent $(n=14)$ indicated that the instruction took place at a public library. Of those who reported having participated in instruction at a college or university library, 17.5 percent $(n=61)$ indicated the instruction took place during their undergraduate programs and 19.2 percent $(n=67)$ indicated that it took place during their graduate programs. With the question being a multiple response, 10 percent $(n=36)$ of respondents reported having had instruction in both the undergraduate and graduate programs. Last, the survey results showed that 26 percent $(n=92)$ of respondents had received instruction from a librarian at an academic library at least once.

\section{Frequency of Information-Seeking Habits for Professional Practice}

A primary purpose of the study was to collect data on the information-seeking habits of educators when looking for information to use in their professional practice, such as information on best practices, classroom management issues, or innovative teaching methods. Frequencies of usage were indicated using a seven-point Likert scale with the options being daily, 2-3 times a week, once a week, 2-3 times a month, once a month, less than once a month, and never. The survey included questions about sixteen specific information resources (see table 1).

Survey results indicated that information sources most frequently used by in-service educators were websites, teachers in one's own department, and the department chair or grade-level leader. Other information sources that were less frequently used were teachers outside one's department, supervisors/administrators, school librarians, materials from professional development workshops or in-service events, reading coaches, professional journals or magazines, online library databases, and publications of the state or federal departments of education. The results for those information sources indicated that more than 70 percent of the respondents used them at least once a month, with less than 50 percent using them on a weekly basis. Finally, the results indicated that the Education Resources Information Center (ERIC) and college textbooks were the resources that many respondents never used for information. Over one third indicated never using ERIC and over one half of respondents indicated never using college textbooks for professional practice.

As part of the analysis, particular attention was given to six library-related information-seeking habits that were of the greatest interest to academic librarians who serve teacher education programs. The six library-related information-seeking habits specifically analyzed for this purpose included: school librarians, professional journals/ magazines, online library databases, state department of education publications, U.S. Department of Education publications, and ERIC. For the school librarians, 35.7 percent of 310 respondents reported that they communicated weekly with the librarian(s) as a resource for professional information; 47.6 percent did the same less than once a week; and 16.7 percent indicated that they never communicated with the librarian(s). For the usage of professional journals/magazines, 28.9 percent of 312 respondents indicated using them at least once a week, 56.7 percent used them less than once a week, and 14.4 percent answered that they never used them. For online library databases, 28.3 percent of 307 respondents indicated using them at least once a week, 51.7 percent used them less than once a week, and 19.9 percent indicated that they never used them. For state department of education publications, 27.4 percent of 310 respondents indicated using them at least once a week, 59.9 used them less than once a week, and 12.6 percent indicated that they never used them. Concerning U.S. Department of Education publications, 12 percent of 308 respondents indicated using them at least once a week, 
TABLE 1

Frequency of Accessing Resources When Seeking Information for Professional Practice

\begin{tabular}{|c|c|c|c|c|c|c|c|c|}
\hline Resources & $\begin{array}{l}\text { Number of } \\
\text { Respondents }\end{array}$ & Daily & $\begin{array}{c}2-3 \\
\text { Times } \\
\text { a Week }\end{array}$ & $\begin{array}{c}\text { Once a } \\
\text { Week }\end{array}$ & $\begin{array}{c}\text { 2-3 } \\
\text { Times a } \\
\text { Month }\end{array}$ & $\begin{array}{l}\text { Once a } \\
\text { Month }\end{array}$ & $\begin{array}{l}\text { Less } \\
\text { than } \\
\text { Once a } \\
\text { Month }\end{array}$ & Never \\
\hline Websites & $\mathrm{n}=318$ & $56 \%$ & $24.8 \%$ & $7.2 \%$ & $5.7 \%$ & $3.8 \%$ & $1.6 \%$ & $0.9 \%$ \\
\hline $\begin{array}{l}\text { Teacher(s) in your } \\
\text { department }\end{array}$ & $\mathrm{n}=306$ & $32.4 \%$ & $23.5 \%$ & $14.1 \%$ & $11.4 \%$ & $5.6 \%$ & $7.2 \%$ & $5.9 \%$ \\
\hline $\begin{array}{l}\text { Dept. chair/grade- } \\
\text { level leader }\end{array}$ & $\mathrm{n}=308$ & $16.6 \%$ & $18.2 \%$ & $16.2 \%$ & $9.7 \%$ & $12 \%$ & $12.7 \%$ & $14.6 \%$ \\
\hline $\begin{array}{l}\text { Teacher(s) outside } \\
\text { your department }\end{array}$ & $\mathrm{n}=302$ & $10.6 \%$ & $15.9 \%$ & $18.5 \%$ & $16.2 \%$ & $13.2 \%$ & $15.2 \%$ & $10.3 \%$ \\
\hline $\begin{array}{l}\text { Supervisor(s)/ } \\
\text { administrator(s) }\end{array}$ & $\mathrm{n}=301$ & $11 \%$ & $11 \%$ & $15 \%$ & $18.3 \%$ & $14 \%$ & $15.3 \%$ & $15.6 \%$ \\
\hline School librarian(s) & $\mathrm{n}=305$ & $9.2 \%$ & $10.5 \%$ & $16.1 \%$ & $19.7 \%$ & $11.5 \%$ & $16.4 \%$ & $16.7 \%$ \\
\hline $\begin{array}{l}\text { Professional } \\
\text { development } \\
\text { workshops/In- } \\
\text { service }\end{array}$ & $\mathrm{n}=315$ & $7.9 \%$ & $14 \%$ & $12.4 \%$ & $26.3 \%$ & $17.8 \%$ & $19 \%$ & $2.5 \%$ \\
\hline Reading coach(es) & $\mathrm{n}=308$ & $8.1 \%$ & $10.7 \%$ & $13 \%$ & $13.6 \%$ & $12 \%$ & $14 \%$ & $28.6 \%$ \\
\hline $\begin{array}{l}\text { Professional } \\
\text { journals/ } \\
\text { magazines }\end{array}$ & $\mathrm{n}=312$ & $7.1 \%$ & $11.5 \%$ & $10.3 \%$ & $23.1 \%$ & $17.3 \%$ & $16.3 \%$ & $14.4 \%$ \\
\hline $\begin{array}{l}\text { Online library } \\
\text { databases }\end{array}$ & $\mathrm{n}=307$ & $5.9 \%$ & $13 \%$ & $9.4 \%$ & $19.2 \%$ & $10.4 \%$ & $22.1 \%$ & $19.9 \%$ \\
\hline $\begin{array}{l}\text { State dept. of } \\
\text { education }\end{array}$ & $\mathrm{n}=310$ & $5.5 \%$ & $11.3 \%$ & $10.6 \%$ & $17.7 \%$ & $19 \%$ & $23.2 \%$ & $12.6 \%$ \\
\hline $\begin{array}{l}\text { Teacher(s) at other } \\
\text { schools }\end{array}$ & $\mathrm{n}=302$ & $5.6 \%$ & $7 \%$ & $13.6 \%$ & $20.9 \%$ & $15.2 \%$ & $25.2 \%$ & $12.6 \%$ \\
\hline $\begin{array}{l}\text { District } \\
\text { supervisor(s)/ } \\
\text { administrator(s) }\end{array}$ & $\mathrm{n}=307$ & $4.6 \%$ & $9.4 \%$ & $8.5 \%$ & $13 \%$ & $9.1 \%$ & $24.4 \%$ & $30.9 \%$ \\
\hline $\begin{array}{l}\text { U.S. Dept. of } \\
\text { Education }\end{array}$ & $\mathrm{n}=308$ & $2.6 \%$ & $4.2 \%$ & $5.2 \%$ & $8.4 \%$ & $12.3 \%$ & $34.7 \%$ & $32.5 \%$ \\
\hline ERIC & $\mathrm{n}=323$ & $0.9 \%$ & $1.5 \%$ & $2.8 \%$ & $11.5 \%$ & $9.9 \%$ & $38.7 \%$ & $34.7 \%$ \\
\hline College textbooks & $\mathrm{n}=305$ & $3 \%$ & $4.6 \%$ & $1.3 \%$ & $4.6 \%$ & $7.2 \%$ & $23.6 \%$ & $55.7 \%$ \\
\hline
\end{tabular}

55.4 percent used them less than once a week, and 32.5 percent indicated that they never used them. Finally, only 5.2 percent of 323 respondents gave indication that they used the ERIC database weekly, 60.1 percent used the database less than once a week, and 34.7 percent indicated that they never use ERIC.

\section{Purposes for Seeking Information}

Survey respondents were asked to indicate specific purposes for which they seek information in their professional practice. A list of seven choices was provided, and respon- 
dents were asked to select multiple answers for this question. Of the 322 respondents who answered the question, the responses were as follows (see figure 1): information for class exercises or projects, 81 percent $(n=261)$; information for lesson planning, 77 percent $(n=250)$; assessment tools and test preparation for students, 61 percent $(n=198)$; news and current events affecting educators and their profession, 59 percent $(n=192)$; information for action research on classroom practices, 52 percent $(n=167)$; information on classroom management issues, 36 percent $(n=116)$; and information for research papers that respondents were writing, 14 percent $(n=46)$.

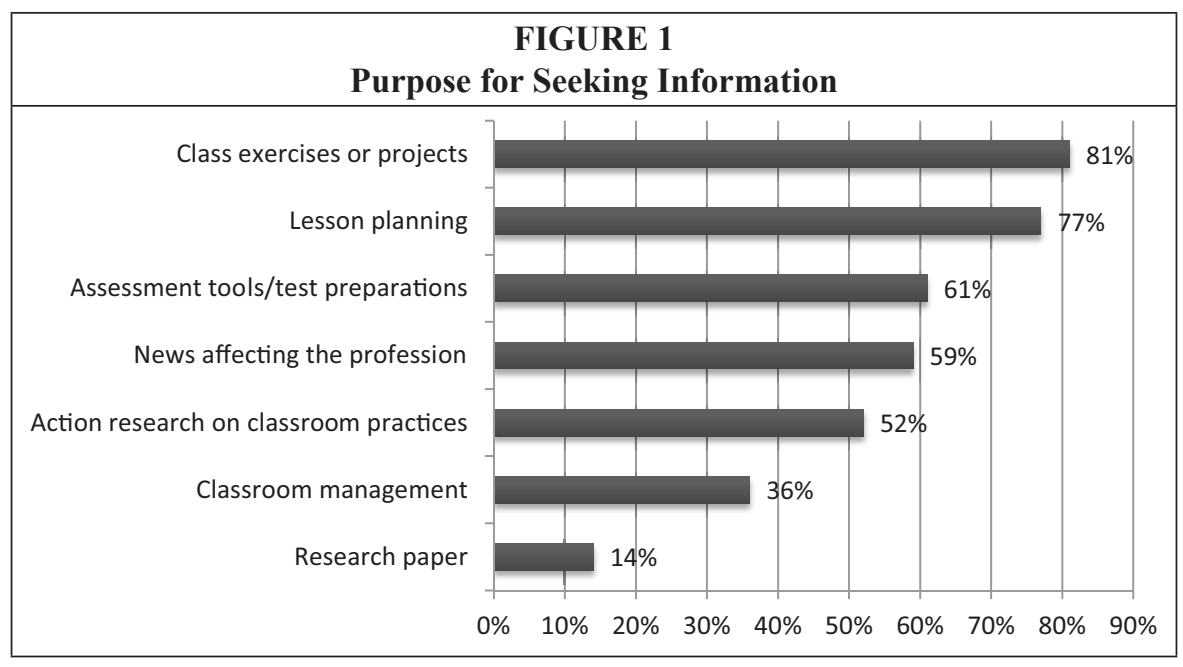

\section{Cross-Tabulations}

Analysis of the data included a Pearson Chi-Square test that was used to determine if any statistically significant relationships would be found between the sixteen information-seeking habits and five variables: age, current position, years of experience, information format, and participation in library database instruction. The test failed to yield results showing a significant relationship between two of the variables, years of experience and preference of information format, and any of the sixteen habits.

The data indicated statistically significant relationships between three of the information-seeking habits and the respondents' ages (see table 2). The habits included seeking information from websites $(p=0.003)$, state department of education publications $(p=0.017)$, and supervisors/administrators $(p=0.039)$, In addition, two other information-seeking habits were trending statistical significance: seeking information using professional journals and magazines $(p=0.063)$ and U.S. Department of Education publications ( $p=0.081$ ). Generation $X$ respondents provided the highest percentages of most frequent use of supervisors/administrators as information resources. On the other hand, the Baby Boomers reported the most frequent use of state department of education publications. Both Generation X and the Millennials indicated more frequent use of websites than the Baby Boomers and the Silent Generation. Last, concerning the two habits that were trending statistical significance, Baby Boomers used U.S. Department of Education publications, as well as professional journals and magazines, the most frequently of all groups. Generation X indicated less frequent usage, and the Millennials indicated the least frequent usage of all. 


\begin{tabular}{|l|c|c|c|}
\hline \multicolumn{4}{|c|}{ TABLE 2 } \\
\hline \multicolumn{4}{|c|}{ Agespondents } \\
\hline Information-Seeking Habits/Resources & $\begin{array}{c}\text { Pearson } \\
\boldsymbol{X}^{2} \text { Value }\end{array}$ & $\boldsymbol{d f}$ & $\boldsymbol{p}$ \\
\hline Websites & 38.733 & 18 & 0.003 \\
\hline State dept. of education & 32.834 & 18 & 0.017 \\
\hline Supervisor(s)/administrator(s) & 29.809 & 18 & 0.039 \\
\hline Professional journals/magazines & 27.941 & 18 & 0.063 \\
\hline U.S. Dept. of Education & 26.870 & 18 & 0.081 \\
\hline Teacher(s) in your department & 22.508 & 18 & 0.210 \\
\hline Teacher(s) outside your department & 17.266 & 18 & 0.505 \\
\hline School librarian & 16.554 & 18 & 0.554 \\
\hline Online library databases & 15.564 & 18 & 0.623 \\
\hline Dept. chair/grade-level leader & 15.499 & 18 & 0.627 \\
\hline College textbooks & 14.560 & 18 & 0.692 \\
\hline Reading coach(es) & 13.927 & 18 & 0.734 \\
\hline Professional development workshops/in-service & 13.629 & 18 & 0.753 \\
\hline District supervisor(s)/administrator(s) & 12.464 & 18 & 0.822 \\
\hline ERIC & 9.839 & 18 & 0.937 \\
\hline Teacher(s) at other schools & 5.533 & 18 & 0.998 \\
\hline
\end{tabular}

The current positions of the respondents also revealed statistically significant relationships to six of the information-seeking habits (see table 3). The six positionrelated habits were seeking information from school librarians $(p=0.000)$, supervisors/ administrators $(p=0.000)$, district supervisors/administrators $(p=0.000)$, reading coaches $(p=0.002)$, state department of education publications $(p=0.017)$, and department chairs/ grade-level leaders $(p=0.017)$.

School administrators provided the highest percentages of frequent use of state department of education publications, supervisors/administrators, department chairs/gradelevel leaders, and district supervisors/administrators. They also indicated moderately frequent use of reading coaches and school librarians as information resources. Likewise, the percentages for school counselors showed similar frequencies in usage of the same resources with the exception of the district supervisors/administrators. School librarians, classroom teachers, and special area teachers indicated moderate to low frequencies for all of the six position-related information-seeking habits; however, school librarians indicated the highest frequency for using school librarians as an information source.

A statistical relationship between the choices of information sources and whether or not the respondents had ever participated in a library instruction session on how to use library databases was found (see table 4). Of the six library-related information-seeking habits, five showed a statistically significant relationship to prior library instruction experience. They included the use of ERIC ( $p=0.001)$, school librarians $(p=0.001)$, online library databases $(p=0.006)$, U.S. Department of Education publications $(p=0.025)$, and state department of education publications $(p=0.028)$. The usage of professional journals and magazines was trending toward statistical significance $(p=0.076)$. None of the other ten information-seeking habits showed a significant relationship to having experienced library instruction with the exception of reading coaches $(p=0.051)$. 


\begin{tabular}{|c|c|c|c|}
\hline \multicolumn{4}{|c|}{$\begin{array}{c}\text { TABLE } 3 \\
\text { Type of Position (Administrator, Teacher, Counselor, etc.) }\end{array}$} \\
\hline Information-Seeking Habits/Resources & \begin{tabular}{|c|c|} 
Pearson \\
$X^{2}$ Value
\end{tabular} & $d f$ & $p$ \\
\hline School librarian & 84.832 & 36 & 0.000 \\
\hline Supervisor(s)/administrator(s) & 106.972 & 36 & 0.000 \\
\hline District supervisor(s)/administrator(s) & 93.710 & 36 & 0.000 \\
\hline Reading coach(es) & 65.392 & 36 & 0.002 \\
\hline State dept. of education & 56.139 & 36 & 0.017 \\
\hline Department chair/grade-level leader & 56.196 & 36 & 0.017 \\
\hline U.S. Dept. of Education & 49.078 & 36 & 0.072 \\
\hline Professional journals/magazines & 48.779 & 36 & 0.076 \\
\hline Teacher(s) in your department & 42.095 & 36 & 0.224 \\
\hline Websites & 39.408 & 36 & 0.320 \\
\hline ERIC & 36.758 & 36 & 0.434 \\
\hline Professional development workshops/in-service & 35.805 & 36 & 0.478 \\
\hline Teacher(s) at other schools & 34.237 & 36 & 0.553 \\
\hline Online library databases & 33.399 & 36 & 0.593 \\
\hline College textbooks & 32.920 & 36 & 0.616 \\
\hline Teacher(s) outside your department & 31.084 & 36 & 0.701 \\
\hline \multicolumn{4}{|c|}{$\begin{array}{c}\text { TABLE } 4 \\
\text { Participation in a Library Instruction Session on Using Online Databases }\end{array}$} \\
\hline Information-Seeking Habits/Resources & $\begin{array}{l}\text { Pearson } X^{2} \\
\text { Value }\end{array}$ & $d f$ & $p$ \\
\hline ERIC & 23.658 & 6 & 0.001 \\
\hline School librarian & 23.691 & 6 & 0.001 \\
\hline Online library databases & 18.037 & 6 & 0.006 \\
\hline U.S. Dept. of Education & 14.495 & 6 & 0.025 \\
\hline State dept. of education & 14.167 & 6 & 0.028 \\
\hline Reading coach(es) & 12.521 & 6 & 0.051 \\
\hline Professional journals/magazines & 11.410 & 6 & 0.076 \\
\hline College textbooks & 9.593 & 6 & 0.143 \\
\hline Websites & 8.965 & 6 & 0.176 \\
\hline Professional development workshops/in-service & 8.117 & 6 & 0.230 \\
\hline Teacher(s) in your department & 7.660 & 6 & 0.264 \\
\hline Teacher(s) outside your department & 3.353 & 6 & 0.372 \\
\hline Supervisor(s)/administrator(s) & 6.130 & 6 & 0.409 \\
\hline Teacher(s) at other schools & 5.049 & 6 & 0.538 \\
\hline Dept. chair/grade-level leader & 3.353 & 6 & 0.763 \\
\hline District supervisor(s)/administrator(s) & 2.046 & 6 & 0.915 \\
\hline
\end{tabular}




\section{Discussion}

This study investigates the information-seeking habits of in-service educators by collecting survey data on demographic information, information format preferences, prior library instruction experience, and respondents' habits using common professional information resources. Survey results indicate that in-service educators use websites most frequently for their information sources. Colleagues and supervisors are also frequently used information sources for educators. On the other hand, library-related information sources, such as online databases, journals, and government publications, appear to be used much less often. Educators may find it more efficient and much easier to search the web or ask a coworker for information than to use information literacy skills to search the databases for research publications. An additional consideration is the possibility that many of the educators who participated in this study find it easier, or perhaps more appealing, to seek information provided in a personal interaction with colleagues, whether in conversation or online, rather than to transfer into their professional practice what they read in research publications, such as Landrum et al. and Williams and Coles describe in their studies. ${ }^{20}$

The survey responses show that in-service educators primarily seek information for writing lesson plans, developing exercises and projects, and developing student assessments. Only a very small percentage of respondents seek research information for writing papers. On the other hand, approximately half of the respondents have indicated that they search for information for action research. Therefore, regardless of the specific purposes for which an information need exists, it is beneficial for professional educators to have the skills and resources to locate, select, and evaluate and appropriately use information, including information on evidence-based practice.

The survey results also show that ERIC is rarely used, with over one third of respondents indicating that they never use it; and the majority who do use it do so on a seldom basis. Additional research into the use of ERIC by in-service educators would be helpful in determining the value this resource may have to professional educators, and it may provide data regarding characteristics or features of the database that will be useful for in-service educators' professional information needs.

Of the selected demographic characteristics, which were analyzed by means of cross-tabulation, only age and type of position show any significant relationships with the sixteen information-seeking habits. Any number of variables in education, work experience, task assignments, professional development, and other factors may likely influence the choice of information sources. But it is interesting to note that age and professional position do show relationships to information-seeking habits. These findings warrant additional research.

When considering information literacy skills and the habits of using library-related resources, the survey results appear to confirm that a relationship exists between information-seeking habits and the information literacy skills that educators are taught in library instruction sessions. Results show statistically significant relationships only between library instruction experience and the six library-related information-seeking habits. Although the data do not establish a cause for these behaviors, the general indication is that library instruction is a key variable in the information-seeking habits that are most likely to provide evidence-based information. This finding becomes an important consideration for academic librarians, school district professional development coordinators, and the teaching faculty in teacher education programs to examine when discussing preservice teacher education and professional development for inservice educators.

The findings of this study also suggest the value of considering the development of newer in-service programs on information literacy that would meet the needs of 
educators. Even though 58 percent of respondents indicate that they have had previous library instruction, the remaining population of educators who never had library instruction remains quite large. An added point to consider is that the respondents only indicated having participated in at least one session. It is likely that a large portion of those educators have only participated in a single library instruction session. Additional systematic instruction would be instrumental in developing information literacy skills that become part of the educators' habits over the course of their careers. In a study of the effect of professional development workshops on teacher-librarian collaboration, Montiel-Overall and Hernández report that the use of professional development workshops may be instrumental in affecting changes in perceptions and behaviors as they relate to teacher-librarian interaction and collaboration. ${ }^{21}$ Ercegovac suggests the fostering of more collaborative partnerships between academic librarians and school librarians as a means of providing information literacy instruction to in-service educators. ${ }^{22}$ Additional research is needed to study the effects of $\mathrm{K}-12$ and postsecondary collaborations and the roles of academic librarians in these projects.

The results indicate that around a quarter of all respondents have participated in library instruction during either their undergraduate or graduate studies at a college or university. Slightly less than 10 percent of respondents received library instruction as undergraduate students and not as graduate students. Consequently, the low percentages of participation in academic library instruction, particularly for undergraduates, may be of importance to academic librarians who evaluate the role that library instruction may play, not only for patrons as students, but also for the alumni working in the profession.

In regard to preservice teacher education programs, the findings of this study may indicate the benefit of increasing the frequency of library instruction sessions for preservice educators during their education programs. Only 21.6 percent of respondents indicated that they had participated in library instruction in a college or university library at an institution where they had earned a degree. An increase in the opportunity to participate in library instruction as part of teacher education is a consideration that needs to be discussed given the increased accessibility to information in the 21st century.

Last, the results of this study indicate the need for further research in the area of information-seeking habits of in-service educators. With so little research on this topic, additional data need to be collected from educators in other areas and regions. More research needs to be conducted to investigate educators' experiences with information literacy instruction and how that instruction affects information-seeking habits.

\section{Conclusion}

As noted by Landrum et al., there is very little published research related to in-service educators and their habits for obtaining information for professional use. ${ }^{23}$ This study, along with further research, may fill a gap in the literature as well as promoting research interest in the information-seeking habits of other professionals. Similar to the findings of LeBaron et al., the results of this study show that a majority of respondents use a broad range of resources when seeking information. ${ }^{24}$ Survey respondents in this study use websites and their colleagues most frequently when they are searching for information for professional use. Library-related resources, such as the online databases, are not as frequently used for work-related purposes. Whether or not respondents have participated in library instruction appears to be a significant variable in relation to habits of using library-related resources. These findings are similar to those of William and Coles and contribute to the discussion of how information literacy instruction relates to the type of information sources that educators use for their profession. ${ }^{25}$

The results of this study suggest that greater participation in library instruction for in-service teachers may be beneficial as they seek information for professional use. 
For academic librarians, what may be more significant is the question of potential relationships that may be found between information literacy instruction in academic libraries and the information-seeking habits of professionals in the field. The findings of this study indicate that more research is needed and that research in this area may be valuable to planning information literacy instruction programs in academic libraries.

\section{Appendix. Survey Questions}

1. Which of the following best describes your position?
administrator/principal
- Classroom teacher
$\square$ Reading coach
S Special area teacher (art, music, PE, enrichment, other.)
- School counselor
School librarian
O Other

2. How many years of work experience do you have as a professional educator in schools?
- $0-5$ years
ㄴ 6 -10 years
口 11 or more years

3. Please indicate each of the college or university degrees you have completed. (Multiple answers allowed.)
Bachelor's degree
- Master's degree
- Specialist degree
D Doctorate

4. Please select the range of years that includes the year when you were born.
ㅁ Before 1946
1946-1964
口 1965-1980
ㄱ 1981 and after

5. Have you ever attended an instructional session conducted by a librarian in which you were presented with information on how to search for articles using an online database?

$\square$ Yes

№

6. If you have participated in library instructional session(s) on using databases, please indicate the library or libraries where instruction took place. (Select all that apply.)

The college or university library at the institution where you earned a bachelor's degree

The college or university library at an institution where you earned a graduate degree

A school library that provided this training to teachers

A public library

- A continuing education workshop

D Not applicable

7. Which is your preferred information format?

P Print

Online 
8. How frequently do you use these resources for professional information (teaching methods, classroom management, best practices, and so on)?

\begin{tabular}{|c|c|c|c|c|c|c|c|}
\hline & Daily & $\begin{array}{c}2-3 \\
\text { times a } \\
\text { week }\end{array}$ & $\begin{array}{l}\text { Once } \\
\text { a } \\
\text { week }\end{array}$ & $\begin{array}{l}2-3 \\
\text { times a } \\
\text { month }\end{array}$ & $\begin{array}{l}\text { Once } \\
\text { a } \\
\text { month }\end{array}$ & $\begin{array}{c}\text { Less than } \\
\text { once a } \\
\text { month }\end{array}$ & Never \\
\hline $\begin{array}{l}\text { Dept. chair/grade-level } \\
\text { leader }\end{array}$ & $\bullet$ & $\bullet$ & $\bullet$ & $\bullet$ & $\bullet$ & $\bullet$ & $\bullet$ \\
\hline $\begin{array}{l}\text { District supervisor(s)/ } \\
\text { administrator(s) }\end{array}$ & $\bullet$ & $\bullet$ & $\bullet$ & $\bullet$ & $\bullet$ & $\bullet$ & $\bullet$ \\
\hline College textbooks & $\bullet$ & $\bullet$ & $\bullet$ & $\bullet$ & $\bullet$ & $\bullet$ & $\bullet$ \\
\hline $\begin{array}{l}\text { Materials from } \\
\text { professional development } \\
\text { workshops/In-service }\end{array}$ & $\bullet$ & $\bullet$ & $\bullet$ & $\bullet$ & $\bullet$ & $\bullet$ & $\bullet$ \\
\hline Online library databases & $\bullet$ & $\bullet$ & $\bullet$ & $\bullet$ & $\bullet$ & $\bullet$ & $\bullet$ \\
\hline Websites & $\bullet$ & $\bullet$ & $\bullet$ & $\bullet$ & $\bullet$ & $\bullet$ & $\bullet$ \\
\hline $\begin{array}{l}\text { Professional journals/ } \\
\text { magazines }\end{array}$ & $\bullet$ & $\bullet$ & $\bullet$ & $\bullet$ & $\bullet$ & $\bullet$ & $\bullet$ \\
\hline $\begin{array}{l}\text { Publications of the state } \\
\text { dept. of education }\end{array}$ & $\bullet$ & $\bullet$ & $\bullet$ & $\bullet$ & $\bullet$ & $\bullet$ & $\bullet$ \\
\hline $\begin{array}{l}\text { Publications of the U.S. } \\
\text { Dept. of Education }\end{array}$ & $\bullet$ & $\bullet$ & $\bullet$ & $\bullet$ & $\bullet$ & $\bullet$ & $\bullet$ \\
\hline Reading coach(es) & $\bullet$ & $\bullet$ & $\bullet$ & $\bullet$ & $\bullet$ & $\bullet$ & $\bullet$ \\
\hline School librarian(s) & $\bullet$ & $\bullet$ & $\bullet$ & $\bullet$ & $\bullet$ & $\bullet$ & $\bullet$ \\
\hline $\begin{array}{l}\text { Supervisor(s)/ } \\
\text { administrator(s) }\end{array}$ & $\bullet$ & $\bullet$ & $\bullet$ & $\bullet$ & $\bullet$ & $\bullet$ & $\bullet$ \\
\hline $\begin{array}{l}\text { Teacher(s) in your } \\
\text { department }\end{array}$ & • & $\bullet$ & • & • & • & $\bullet$ & $\bullet$ \\
\hline $\begin{array}{l}\text { Teacher(s) outside your } \\
\text { department }\end{array}$ & $\bullet$ & $\bullet$ & • & $\bullet$ & - & • & • \\
\hline $\begin{array}{l}\text { Teacher(s) at other } \\
\text { schools }\end{array}$ & • & • & • & • & • & $\bullet$ & • \\
\hline
\end{tabular}

9. How often do you use the ERIC (Educational Resources Information Center) online database?
口 Daily
2-3 times a week
- Once a week
- 2-3 times a month
Once a month
L Less than once a month
Never 
10. For what purpose do you seek information for use in your profession? (Select all that apply.)

- Action research on classroom practices

Class exercises or projects

Classroom management issues

Lesson planning

Research paper that you are writing

- Assessment tools/test preparation for students for the class(es) you teach

Aware of news and current events affecting educators and their profession

\section{Notes}

1. Association of College and Research Libraries, Information Literacy Competency Standards for Higher Education (Chicago: ACRL, 2000).

2. Association of College and Research Libraries, "Information Literacy Standards for Teacher Education," CERL News 72 (July/August 2011): 420-26, 436.

3. Nancy O'Hanlon, "The Role of Library Research Instruction in Developing Teachers' Problem Solving Skills," Journal of Teacher Education 39, no. 6 (1988a): 44-49; Nancy O'Hanlon, "Up the Down Staircase: Establishing Library Instruction Programs for Teachers," RQ 27, no. 4 (1988b): 528-34.

4. Godfrey Franklin and Ronald C. Toifel, "The Effects of BI on Library Knowledge and Skills Among Education Students," Research Strategies 12, no. 4 (1994): 224-37.

5. Ronald C. Toifel and Godfrey Franklin, "Using Technology to Teach Preservice Students about Locating Information in the Academic Library," Journal of Educational Technology Systems 27, no. 2 (1998): 133-45.

6. Jennifer L. Branch, “Teaching, Learning and Information Literacy: Developing an Understanding of Preservice Teachers' Knowledge," Behavioral \& Social Sciences Librarian 22, no.1 (2003): 33, doi:10.1300/J103v22n01_04.

7. Raziye Demiralay and Sirin Karadeniz, "The Effect of Use of Information and Communication Technologies on Elementary Student Teachers' Perceived Information Literacy Self-efficacy," Educational Sciences: Theory and Practice 10, no. 2 (2010): 841-51.

8. Marlene Asselin and Ray Doiron, "Whither They Go: An Analysis of the Inclusion of School Library Programs and Services in the Preparation of Pre-service Teachers in Canadian Universities," Behavioral \& Social Sciences Librarian 22, no. 1 (2003): 19-32, doi:10.1300/J103v22n01_03; Marlene M. Asselin and Elizabeth A. Lee, "I Wish Someone Had Taught Me: Information Literacy in a Teacher Education Program," Teacher Librarian 30, no. 2 (2002): 10-17; Warren F. Crouse and Kristine Esch Kasbohm, "Information Literacy in Teacher Education: A Collaborative Model," The Educational Forum 69, no. 1 (2004): 44-52; Mark Emmons et al., "Teaching Information Literacy Skills to Prepare Teachers Who Can Bridge the Research-to-Practice Gap," Reference \& User Services Quarterly 49, no. 2 (2009): 140-50; Vanessa Earp, "Integrating Information Literacy into Teacher Education: A Successful Grant Project," Behavioral \& Social Sciences Librarian 28, no. 4 (2009): 166-78, doi: 10.1080/01639260903275748; Deborah Floyd, Gloria Colvin, and Yasar Bodur, "A Faculty-Librarian Collaboration for Developing Information Literacy Skills among Preservice Teachers," Teaching and Teacher Education: An International Journal of Research and Studies 24, no. 2 (2008): 368-76; Afton McGrath Miner, "Impact and Implications of a Library-use Integrated Education Program," The Reference Librarian 10, no. 24 (1989): 257-67, doi:10.1300/J120vl0n24-21; Steve W. Witt and Julia B. Dickinson, "Teaching Teachers to Teach: Collaborating with a University Education Department to Teach Skills in Information Literacy Pedagogy," Behavioral and Social Sciences Librarian 22, no. 1 (2003): 75-96, doi:10.1300/J103v22n01_06.

9. Penny Beile, "Development and Validation of the Information Literacy Assessment Scale for Education (ILAS-ED)" (paper, Montreal, Canada, April 12, 2005).

10. Teaching Information Retrieval and Evaluation Skills to Education Students and Practitioners: A Casebook of Applications, eds. Patricia O'Brien Libutti and Bonnie Gratch (Chicago: Association of College and Research Libraries, American Library Association, 1995).

11. Lolly Templeton and Signia Warner, "Incorporating Information Literacy into Teacher Education," Academic Exchange Quarterly 6, no. 4 (2002): 71-76; Tobeylynn Birch et al., "Partnering with Librarians to Meet NCATE Standards in Teacher Education," Education 128, no. 3 (2008): 369-79.

12. Association of College and Research Libraries, "Information Literacy Standards for Teacher 
Education."

13. John F. LeBaron et al., "How Educators Find Education Resources on the Internet: A Discussion of Independent Search Behaviors by Graduate Education Students," The Internet and Higher Education 1, no. 3 (1998): 191-201.

14. Timothy J. Landrum et al., "Teacher Perceptions of the Useability of Intervention Information from Personal Versus Data-based Sources," Education \& Treatment of Children 30, no. 4 (2007): 27.

15. Dorothy Williams and Louisa Coles, "Evidence-based Practice in Teaching: An Information Perspective," Journal of Documentation 63, no. 6 (2007a): 812-35; Dorothy Williams and Louisa Coles, "Teachers' Approaches to Finding and Using Research Evidence: An Information Literacy Perspective," Educational Research 49, no. 2 (2007b): 185-206, doi:10.1080/00131880701369719.

16. Anne Marie Perrault, "An Exploratory Study of Biology Teachers' Online Information Seeking Practices," School Library Media Research 10 (2007): 1-26.

17. Association of College and Research Libraries, "Information Literacy Standards for Teacher Education."

18. Teresa Y. Neely, "Aspects of Information Literacy: A Sociological and Psychological Study" (PhD diss., University of Pittsburg, 2000), in ProQuest (AAT 9974460).

19. Association of College and Research Libraries, "Information Literacy Standards for Teacher Education."

20. Landrum et al., "Teacher Perceptions of the Useability of Intervention Information"; Williams and Coles, "Evidence-based Practice in Teaching"; Williams and Coles, "Teachers' Approaches to Finding and Using Research Evidence."

21. Patricia Montiel-Overall and Anthony C.R. Hernández, “The Effect of Professional Development on Teacher and Librarian Collaboration: Preliminary Findings Using a Revised Instrument, TLC-III," School Library Research 15 (2012): 1-25.

22. Zorana Ercegovac, "Bridging the Knowledge Gap between Secondary and Higher Education," College \& Research Libraries 64, no. 1 (2003): 75-85.

23. Landrum et al., "Teacher Perceptions of the Useability of Intervention Information."

24. LeBaron et al., "How Educators Find Education Resources on the Internet."

25. Williams and Coles, "Evidence-based Practice in Teaching"; Williams and Coles, "Teachers' Approaches to Finding and Using Research Evidence." 